On the other hand, Cidaris Bowerbanki is a characteristio and easily recognisable fossil in the Chalk above the zone of $A$. varians as understood by me. It has only been recorded in the lower zone near Lewes, and does not occur in the 'Totternhoe Stone.' As an index, it seems much more suitable and definite than any of those species suggested by Mr. Jukes-Browne.

I still maintain, however, that it is more practicable to use the "Two Holasters," which are commoner fossils; and it does not seem unreasonable to use in partnersbip two contemporary species of different habitat to indicate beds deposited under variable conditions at the same time. Mr. Jukes-Browne has shown at some length that my brief summary of the occurrences of Holaster subglobosus contains some inaccuracies. This I am willing to admit; but the necessary corrections do not affect the main conclusion-that it requires the two Holasters to define the whole zone.

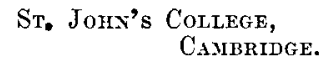

T. O. Bosworth.

OBITUARY

\title{
FREDERICK JUSTEN, F.L.S.
}

Borx Febrtary 29, 1832.

Died Yoveyrer 20, 1906.

IT is with deep regret that we record the death, on Tuesday, 20 th November, of our dear and valued friend, Mr. Frederick Justen, F.L.S., the publisher of this journal.

Mr. Justen was born at Bonn on the 29th February, 1832, and came to England as a German Assistant to the firm of Messrs. Dulau \& Co., 37, Soho Square, W., in 1851.

Upon the decease of the late Mr. Twentyman, the then acting partner, Mr. Justen became the sole proprietor of the firm, and for many years devoted his energies to supplying the requirements of the British Museum and the Libraries of the various scientific societies of London and the provinces with foreign publications.

It was his strong sympathy with the aims and objects of the Geological and Palæontographical Societies, the Geologists' Association, and other kindred institutions, that prompted him, in 1895-irrespective of any pecuniary considerations whateverto undertake the publication of the Geological Magazine, in the success of which he always took the deepest interest.

It is not too much to affirm that the onward progress of the Geologidal Magazine in the last 12 years has been mainly due to the public-spirited support given to it by Mr. Frederick Justen, and no one of all our friends and supporters rejoiced more than he did, when, in February last, the 500th monthly number of this journal was issued from 37 , Soho Square.

Notwithstanding the great personal loss which the death of Mr. Justen has caused to us, we are happy to state that the business relations with the firm of Messrs. Dulau and Company will be continued in the same cordial manner as heretofore.

H. W. 